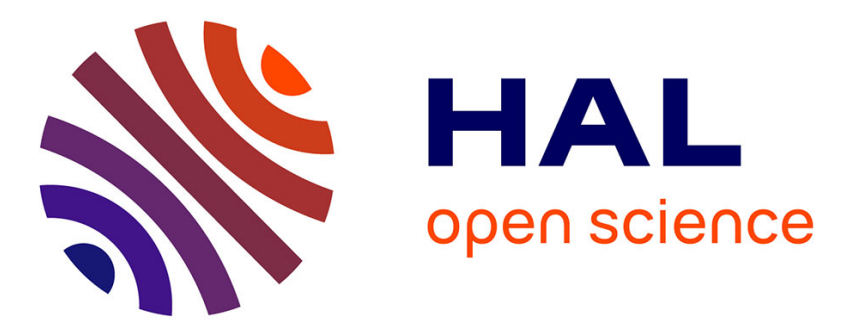

\title{
Rainfall continentality, via the winter Gams angle, provides a new dimension to biogeographical distributions in the western United States
}

Richard Michalet, Philippe Choler, Ragan Callaway, Thomas Whitham

\section{To cite this version:}

Richard Michalet, Philippe Choler, Ragan Callaway, Thomas Whitham. Rainfall continentality, via the winter Gams angle, provides a new dimension to biogeographical distributions in the western United States. Global Ecology and Biogeography, 2021, 30 (2), pp.384-397. 10.1111/geb.13223 . hal-03451970

\author{
HAL Id: hal-03451970 \\ https://hal.science/hal-03451970
}

Submitted on 28 Nov 2021

HAL is a multi-disciplinary open access archive for the deposit and dissemination of scientific research documents, whether they are published or not. The documents may come from teaching and research institutions in France or abroad, or from public or private research centers.
L'archive ouverte pluridisciplinaire HAL, est destinée au dépôt et à la diffusion de documents scientifiques de niveau recherche, publiés ou non, émanant des établissements d'enseignement et de recherche français ou étrangers, des laboratoires publics ou privés. 
1 Rainfall continentality, via the winter GAMS angle, provides a

2 new dimension to biogeographical distributions in the Western

3 United States

4

5 Running Title: Woody plant distributions and continentality

7 Richard Michalet $^{1 *}$, Philippe Choler ${ }^{2}$, Ragan M. Callaway ${ }^{3} \&$ Thomas G. $^{4}$

8 Whitham

${ }^{1}$ University of Bordeaux, UMR CNRS 5805 EPOC, F-33405 Talence, France

${ }^{2}$ Univ. Grenoble Alpes, Univ. Savoie Mont-Blanc, CNRS, LECA, F-38000

Grenoble, France

${ }^{3}$ Division of Biological Sciences, University of Montana, Missoula, MT 59812,

15 USA

${ }^{4}$ Department of Biological Sciences and Merriam-Powell Center for

Environmental Research, Northern Arizona University, Flagstaff, Arizona 86011 USA

*Correspondence: E-mail: richard.michalet@ecologie.u-bordeaux.fr 


\section{Abstract}

Aim: Drought stress has focused on water availability during the growing season, thus primarly on summer. However, variation in rainfall continentality can produce striking vegetation differences. We aim to disentangle summer water balance from winter rainfall continentality, to better understand how climate regulated the distributions of woody plants in the western USA.

\section{Location: Western USA.}

\section{Time period: Actual.}

Major taxa studied: Angiosperms and Conifers.

Method: We used Redundancy Analysis (RDA) to investigate correlations between rainfall continentality, summer water balance, minimum winter temperature and length of growing season on the distributions of 130 tree and shrub species in 467 plots. Rainfall continentality was calculated using the Gams (1932) index, modified for winter precipitation, and summer water balance with the ratio of summer precipitation to temperature. We estimated Actual EvapoTranspiration (AET), Deficit (DEF), mean annual temperature and rainfall from global gridded datasets and correlated them with RDA axes.

Results: Rainfall continentality measured with the Gams index and minimum temperatures best explained the contrast between oceanic vegetation in the Pacific Coast Ranges and continental vegetation in the Intermountain Region and Rocky Mountains. Growing Season Length (GSL) was the second strongest factor correlated with vegetation distributions. Summer water balance, despite being the most widely used climatic factor to assess drought stress in biogeography, was the third strongest factor correlating with vegetation classes of the western US. AET was equally correlated with RDA axes 1 and 3, and, thus, could not discriminate between the contrasts in the RDA.

Main conclusions: Rainfall continentality measured with the winter Gams index provides a more precise metric than summer water balance for understanding the biogeography of woody plants in the western USA. Broadly integrating the Gams index of continentality into plant distributions may improve our understanding of biogeographical distributions and predictions of responses to climate change. 
51 Key-words: Drought, Growing season length, Minimum temperature, Rainfall continentality, Rain shadow effects, Water balance, Western USA, Winter rainfall

53 


\section{Introduction}

For decades, water balance during the growing season has been the key measurement used to quantify drought stress in ecological, biogeographical, physiological and climate change studies, likely due to the primary objective of pioneer biogeographers to separate Mediterreanean from temperate climates (Walter \& Lieth, 1960; Stephenson, 1990; Rueda, Godoy \& Hawkins, 2018; Williams et al., 2020). For example, the ombrothermal diagram proposed by Bagnouls \& Gaussen (1953) for the Mediterranean Basin, in Europe and northern Africa, has been widely and successfully used worldwide to describe biogeographical distributions (Walter \& Lieth, 1960). Stephenson $(1990,1998)$ proposed measurements of Actual EvapoTranspiration (AET) and Deficit (DEF), which integrate evaporative demand with available water for plant performance. AET and DEF indices have been applied to water balance in several biological and ecosystem processes and to simulate climate change (Franck \& Inouye, 1994; Rehfeldt, Crookston, Warwell, \& Evans, 2006).

However, indices quantifying water balance during the growing season might be limited in biogeographic explanatory power when growing season length exceeds seven to eight months, because they integrate both the effects of summer water balance and the effects of winter and early spring rainfall. This is particularly important in areas with both Mediterranean and highly continental climates, such as the western USA. In oceanic Mediterranean climates annual AET (AETy) is highly influenced by the high winter and spring rainfall but not by the very low summer rainfall (AET in winter and in spring contributes to 39 and 36 vs. $2.7 \%$ of AETy, respectively, in southern California, USA; Fig. 1a). In contrast, in continental subtropical climates, AETy is weakly influenced by the low winter and spring rainfall but strongly influenced by the high summer rainfall (AET in winter and in spring contributes to 9.7 and 18 vs. $48.2 \%$ of AETy, respectively, in New Mexico, USA; Fig. 1b). These two regions, located at similar latitude and altitude, have very similar AETy and DEFy (Fig. 1c), but they have strikingly different climates in terms of summer water balance and rainfall continentality (Fig. 1d).

Rainfall continentality effects, in which continental interior regions are insulated from oceanic influences, is a decrease in precipitation induced by the penetration of low pressure air on a continent (Schermerhorn, 1967; Bach, Price, Dorn, Liu, \& Phillips, 2013). Most low atmospheric air pressure systems have oceanic origins, but they can also originate on inland seas, such as the Mediterranean, Black and Caspian seas in Europe (Michalet, 1991; Pache, 
Michalet, \& Aimé, 1996a; Caccianiga et al., 2008). In temperate and Mediterranean climates, rainfall continentality primarily affects winter precipitation, whereas in tropical monsoon climates these effects can also be strong in summer (Michalet, 1991; Bach et al., 2013). Rainfall continentality effects are much stronger where mountain ranges are adjacent to oceans, due to the increase in precipitation with increasing altitude on the windward sides of mountains (orographic effect, Browning \& Hill, 1981) and a decrease on their leeward sides (rain shadow effect, Roe, 2005). Since Vapor-Pressure Deficit (VPD) increases and cloudiness decreases along gradients of increasing rainfall continentality, temperature range increases in continental climates, due to increasing irradiance, with colder winter nights and warmer days than in oceanic climates (Waring \& Franklin, 1979; Bach et al., 2013). The increase in day temperature, in particular in the spring, increases growing season length, which explains shifts in vegetation belts to higher altitudes in continental mountain ranges than in oceanic ranges (Ozenda, 1985; Grace, 1987; Michalet, 1991; Desplanque, Rolland, \& Michalet, 1998; Michalet et al., 2003; He et al., 2016 and see Fig. 2).

Precipitation-based continentality creates striking differences in vegetation in a wide range of climates, and this has major ecological and evolutionary consequences. One of the best examples is in the temperate climate of northwestern America, where mountains and distance from ocean creates the difference between the rainforests of the Pacific Coast and the dry coniferous forests of the Rocky Mountains (Daubenmire, 1946; Franklin \& Dyrness, 1973; del Moral \& Watson, 1978; Waring \& Franklin, 1979). This difference in vegetation is a major component of classification in the US (Brown, Reichenbacher, \& Franson, 1998). Similar differences, though less strong, occur at the same latitudes in temperate Europe between the mixed deciduous-evergreen beech-fir (Fagus sylvatica-Abies alba) forests of the external (oceanic) Alps and the larch-pine (Larix decidua-Pinus sylvestris-P. uncinata) forests of the inner (continental) Alps (Gams, 1932; Ozenda, 1985; Pache et al., 1996a; Michalet, Joud, Gafta, Rolland, \& Callaway, 2003).

Although precipitation-based, or rainfall continentality and rain shadow effects, produce striking vegetation patterns on several continents, there has been little attention to winter precipitation in biogeographical patterns, likely because plants are generally dormant during the cold season. An important exception is the use of winter vs. summer precipitation to predict shrub vs. grass dominance, respectively, in US deserts and shrub steppe (Neilson 1986, 1987; Paruelo \& Lauenroth, 1996; Munson et al., 2013; Reinhardt, McAbee, \& Germino, 2019). The most direct physiological stress associated to rainfall continentality is 
likely the much higher VPDs in continental climates that affect stomatal conductance, water uptake and carbon assimilation (Simonin, Santiago, \& Dawson, 2009; Muhamed, Le Bagousse-Pinguet, Touzard, \& Michalet, 2013; Novick et al., 2016). Also, the frequency of freezing temperatures increases substantially in dry continental air (Bach et al., 2013), and together with higher irradiances, increase photo-inhibition (Manuel et al., 1999). This is highly detrimental for species with high leaf area and Specific Leaf Area (SLA) (Waring, Emmingham, Gholz, \& Grier, 1978). Importantly, plants must cope with these constraints during the growing season, since the low cloudiness of continental climates is observed yearlong (Peyre, 1983). Sequoia sempervirens, in northern California, is tightly correlated with overcast conditions (Waring \& Franklin, 1979; Barbour et al., 2014), perhaps an example of distributional limits imposed by high VPD in continental climates through leaf physiological traits.

In Europe there is a history of using variation in annual rainfall as an indicator of rainfall continentality in mountains (Gams, 1932; Ozenda, 1985). In the Alps of Switzerland, Gams (1932) proposed a rainfall continentality index, based on the rate of increase in precipitation with elevation and quantified with the angle of which the co-tangent is equal to the ratio of annual precipitation to elevation. It allows researchers to compare the rainfall continentality of sites differing in elevation, a task that cannot be accomplished with the only comparison of the precipitation of the sites. This is crucial since altitude and rainfall continentality are complex factors that drive different direct factors for plants, both for temperature and humidity. Thus, one main interest of the Gams-angle index is to disentangle in mountain ranges the effects of rainfall continentality from that of decreased precipitation with decreasing altitude (i.e., orographic effect). Gams (1932) showed that the distribution of European beech (Fagus sylvatica) was tightly related to variation in the index, with values below $45^{\circ}$ in the external Alps where beech dominates the mountain belt, vs. above $45^{\circ}$ in the inner Alps where beech is replaced by Scots pine (Pinus sylvestris) and European larch (Larix decidua). Ozenda (1985) generalized the "Gams-angle" approach throughout the Alpine Chain (see also Michalet et al., 2003 and Caccianiga et al., 2008) and Michalet (1991) applied the Gams-angle index to the Mediterranean climate of Morocco.

Michalet (1991) also proposed a climagram combining three important dimensions of mountain biogeography (rainfall continentality, altitude and aridity), that depicts the distribution of plant species both in the geographical and ecological spaces, (Fig. 2). Interestingly, plant species have an oblic distribution in the climagram in direct relation with 
the aridity zones of Emberger (1930), due to their occurrences at lower elevations in oceanic than continental climates. This means that, consistent with Emberger (1930), species have specific water balance requirements, from very humid to sub-humid for oceanic species, humid to semi-arid for semi-oceanic species and sub-humid to arid for continental species (Fig. 2). These specific water balance conditions can occur at low altitude in oceanic climates, due to high precipitation occurring at low altitude, but only at high altitude in continental climates, due to a lower rate of increasing precipitation with increasing altitude. Thus, this climagram allows to better understand the link existing between the humidity (VPD) and cold stress that is only captured by the Gams index of rainfall continentality. Oceanic species are adapted to warmer climates than continental species since the specific water balance requirements can be found at lower elevation for the former than for the latter. Additionally, this climagram allows a display of the above-mentioned shift of vegetation belts to higher altitudes with increasing continentality. This shift likely contributes to the strong vegetation turnover occurring from oceanic to continental climates, since nights are colder in continental than oceanic climates, thus amplifying cold stress for oceanic species. Crucially, Pache et al. (1996a) proposed a seasonal modification of the Gams-angle index that targeted winter precipitation (December to February), which provided a precipitation-based continentality index. We propose that this index provides a better metric than indices of growing season precipitation for assessing biogeographical patterns from areas with high seasonal variation in rainfall due to large ranges in latitude, like those from the Mediterranean Basin in Europe and Africa or from western North-America.

Our main objective is to assess the relative importance of rainfall continentality and summer water balance in driving biogeographical distribution in areas subjected to strong variation in winter and summer rainfall. The western USA has striking vegetation contrasts on gradients of rainfall continentality. Rainfall continentality occurs across a seasonal latitudinal gradient in rainfall, temperate in the north, Mediterreanean in the southwest and with subtropical influences in the southeast. Thus, this system is very appropriate for assessing our main objective. We sampled vegetation throughout the 11 states of western USA, establishing 467 vegetation plots near climate stations from which we extracted several climate indices to correlate them to vegetation composition using Redundancy Analysis (RDA). We partitioned vegetation plots in 16 groups with a cluster conducted on RDA results and mapped their distribution throughout the 11 states. We also extracted data from the Worldclim database for regional spatial variation in the main climate variables, including the Gam index for rainfall 
continentality in the winter (Pache et al., 1996a). We finally analysed the relationship between the Gams-angle index and AETy, DEFy (Stephenson, 1998), Mean Annual Precipitation (MAP) and Mean Annual Temperature (MAP) that are commonly used in the literature. We made two main hypotheses: (1) variation in rainfall continentality quantified by the Gamsangle index provides a better metric for quantifying vegetation in Western USA than summer water balance (2) variation in rainfall continentality quantified by the Gams-angle index provides a better metric for quantifying vegetation in Western USA than the current accepted metric of water availability during the growing season (AETy and DEFy).

\section{Material and methods}

\section{Study area}

We focused on 11 states in western USA (Fig. 2). This geographical area, well separated from the American Prairie further east, may be subdivided into three main geographical units: (1) the western Pacific Coast Ranges sensu lato, located in the western parts of Washington State (WA), Oregon (OR) and California (CA) and including the coastal ranges sensu stricto and the Cascade and Sierra Nevada ranges, (2) the Intermountain Region, including the Great Basin, Colorado Plateau and southern deserts, mostly located in the eastern parts of the former states and south-west Idaho (ID), Nevada (NV), Utah (UT) and Arizona (AZ, (3) the Rocky Mountains to the east of the study area, in eastern ID, Montana (MT), Wyoming (WY), Colorado (CO) and New Mexico (NM). When considering seasonal rainfall distribution and mean temperatures, five main climatic influences characterize the study area following Walter \& Lieth (1960), temperate oceanic in the northwest, mostly limited to WA, OR and ID, Mediterranean in the south-west, only in western CA, continental temperate in the northeast, in MT, WY and CO, continental and slightly subtropical in the southeast, in AZ and NM, and arid-desertic in the southern parts of the Intermountain Region, in UT, NV, eastern CA, and southern AZ and NM.

\section{Climatic data and vegetation sampling}

We collected climate data from 800 weather stations in the Western Regional Climate Center (https://wrcc.dri.edu/) for the study area. We used the elevation of the stations and, for the period 1971-2000, the precipitation and minimum and maximum temperatures over 12 months. To address our main goal, separating rainfall continentality from summer water balance, we calculated for each weather station the Gams-angle rainfall continentality index 
using winter (December, January and February) precipitation (W GAMS, Pache et al., 1996a), and a summer water balance index, S ARID, calculating the ratio between the precipitation and the mean of maximum temperatures of the three summer mmonths (June, July and August). For cold stress, we used the minimum temperature of the coldest month for coldtolerance (Tmin), and the number of months with a maximum temperature above $12.5^{\circ} \mathrm{C}$ for the Growing Season Length (GSL). For rainfall continentality, we calculated W GAMS with winter precipitation using three different formulas depending on elevation (after Michalet et al., 2003), which accounted for non-linearity in increasing precipitation with increasing elevation (Michalet, 1991):

- From 900 to $1600 \mathrm{~m}$, we used the original formula of Gams (1932): $\operatorname{Cotg}(\alpha)=4 \mathrm{P} / \mathrm{A}$, Where $\alpha$ is the W GAMS index and P is the winter precipitation in $\mathrm{mm}$ and $\mathrm{A}$ the elevation in meters.

- $\quad$ Below 900 m, we used a modified Gams formula (Michalet, 1991):

$\operatorname{Cotg}(\alpha)=(4 \mathrm{P}-((900-\mathrm{A}) / 100) *(4 \mathrm{P} / 10))) / \mathrm{A}$

With $\mathrm{A}=100 \mathrm{~m}$ when elevation below $100 \mathrm{~m}$.

- Above 1600 m, we used a second modified Gams formula (Pache, Aimé, \& Michalet, 1996b):

$$
\operatorname{Cotg}(\alpha)=(4 \mathrm{P}+((\mathrm{A}-1600) / 100) *(4 \mathrm{P} / 20))) / \mathrm{A}
$$

For vegetation sampling, we selected 467 plots near weather stations (see statistical analyses) in order to get the vegetation composition of sites where climate variables were really measured. This sampled the climatic diversity of the total study area, while spatially distributing the sampling. Fieldwork was carried out between 2000 and 2010, at different times of the year depending on the growing season length and leaf phenology of the deciduous species in different areas. We recorded the presence or absence of all tree species and dominant shrubs at less than $5 \mathrm{~km}$ from each corresponding weather station, taking care not to sample species at more than $100 \mathrm{~m}$ of elevation higher or lower than the weather station. Considering the scale of the study, we sampled at all exposures and on all soil types within the plots.

We also extracted from Worldclim2 database (Fick \& Hijmans, 2017) the former selected variables for estimating annual Actual EvapoTranspiration (AETy), annual Deficit (DEFy), Mean Annual Temperature (MAT) and Mean Annual Precipitation (MAP) for postanalyses correlations. The water balance-related variables (AETy and DEFy) were calculated according to Stephenson (1990). The Available Water Capacity (AWC) was retrieved from 
the USDA State Soil Geographic Database (Miller \& White, 1998). AWC data for the first $100 \mathrm{~cm}$ have been used.

\section{Statistical analyses}

We conducted a Principal Component Analysis on the 800 weather stations and four climates indices extracted from the Western Regional Climate Center (W GAMS, S ARID, Tmin and GSL). A cluster analysis was conducted on PCA scores in order to select 467 stations among the climate types. We then performed a Redundancy Analysis (RDA) - also known as a multivariate analysis with respect to instrumental variables - to study species-environment relationships. RDA is a two-table ordination technique in which the environmental table - i.e., the predicting set of variables - is analyzed by a PCA of a correlation matrix, and the floristic table - i.e., the response set of variables - is analysed by a PCA of a covariance matrix. The algorithm searches for the linear combination of environmental variables that best capture community structure (Dray \& Chessel, 2003). The environmental table included the same four climate variables as in the PCA, plus winter precipitation (W PREC). Plant species with a frequency lower than five out of the 467 plots were excluded from the analysis. The final floristic table contained 130 species. To benchmark our results with other studies, we projected AETy, DEFy, MAT and MAP on the three first RDA axes. Multivariate analyses were conducted in R ( $\mathrm{R}$ core team, 2017) with the library ade4 (Dray \& Dufour, 2007).

The partitioning of vegetation plots was performed on a dissimilarity matrix estimated with the Jaccard's index (Jaccard, 1901). We used the Partitioning Around Medoids (PAM) technique (Kaufman \& Rousseeuw, 2009) implemented in the library CLUSTER (Maechler, Rousseeuw, Struyf, Hubert, \& Hornik, 2019) to search for k representative objects or medoids among the observations. The algorithm assigns each observation to the nearest medoid with the objective of minimizing the sum of dissimilarities between groups. The method utilizes a prescribed number of medoids. We found that the value $\mathrm{k}=16$ was providing an ecologically and biogeographically meaningful partition of relevés while retaining a sufficient number of relevés per group.

\section{Results}

In the RDA, the total unconstrained inertia was 5.55 and the sum of eigenvalues was 1.13, indicating that $20.4 \%$ of the total floristic variance was explained by environmental variables (Appendix S1). The RDA axes accounted for 40\%, 29\%, 20\%, 8\% and 3\% of the explained 
variance. Given the drop between axis 3 and axis 4, we did not consider the last two RDA axes in further analyses. In agreement with our first hypothesis, RDA Axis 1 was more positively correlated with rainfall continentality quantified by the Gams-angle index (W GAMS; $r=0.99$ ) than any other variable, negatively with winter precipitation (W PREC; $r=-$ 0.87 ) and less so with minimum temperatures (Tmin; $r=-0.63$ ) (Fig. 4A, Table 1). RDA Axis 2 was highly negatively correlated with growing season length (GSL; $r=-0.87$ ) and less with cold temperature $(\mathrm{Tmin} ; \mathrm{r}=-0.72)$.

RDA Axes 1-2 were also highly correlated with the plant biogeography of the western USA. The temperate rain forests of the Pacific Coast Ranges and Mediterranean evergreen oak forests (cluster groups 1 and 11, respectively) aggregated on the extreme left of Axis 1 . In contrast, the coniferous forest and woodland communities from central Montana and eastern pinion-juniper woodlands in the central and southern Rocky Mountains aggregated on the extreme right of Axis 1 (cluster groups 6 and 10, respectively, Fig. 3a, 4a, b, Tables 1, 2). The upper end of Axis 2 was occupied by the northwestern and eastern subalpine coniferous forest communities (cluster groups 12 and 9, respectively) and the lower end by the subtropical desert communities of the Sonoran Desert and evergreen oak woodlands of AZ and NM (cluster groups 4 and 5, respectively, Fig. 3a, 4a, b, Tables 1,2). The west-east climatic contrast on Axis 1 can be seen on the W GAMS and Tmin maps and the north-south contrast on Axis 2 on the Tmin map only (Fig. 3b, c). The contrast between the oceanic vegetation of the Pacific Coast Ranges and the continental vegetation of the Rocky Mountains and Intermoutain Region was distinct, with few species in common between the two zones or in intermediate positions on the gradient (see Appendix S2 in supporting information, and the low number of communities occurring at intermediate position along Axis 1 in Fig. 4b, i.e, only $12,16,8)$. Species occurring along the whole gradient of continentality were represented by different subspecies in each zone, e.g., Pinus ponderosa var. ponderosa, Pseudotsuga menziesii var. menziesii and Pinus contorta var. muryana in the west vs. P. ponderosa var. scopulorum, P. menziesii var. glauca and P. contorta var. latifolia in the east.

RDA Axis 3 was strongly correlated with summer water balance (S ARID; $r=-0.86$, Appendix S3, Fig. 4c) and also weakly with Tmin and GSL (Table 1). Within oceanic climates, i.e., on the left of Axis 1, Axis 3 separated Mediterranean communities with a dry summer (cluster 11 and 8 - CA evergreen oak forests and southern chaparral, respectively) from temperate communities with a wet summer (clusters 1 and 12 - coastal temperate rain forests and north-western subalpine forests, respectively). Within continental climates, i.e., on 
the right of Axis 1, Axis 3 separated communities of the Great Basin with a dry summer, the mountain Ponderosa pine woodlands and the pinion-juniper woodlands (clusters 2 and 3, respectively), from mountain and subalpine coniferous forest communities of the Rocky Mountains (cluster groups 9 and 7, respectively) with wet summers (Fig. 3a, 4d, Tables 2, S1.1).

Oceanic climates with low W GAMS values always had high Tmin, but continental climates with high W GAMS values were highly variable in Tmin (Fig. 5a), consistent with the high positive correlation with RDA Axis 1 (Table 1, Fig. 3b, c). In contrast, there was no correlation between W GAMS and S ARID (Fig. 5b), which is consistent with the co-linearity with the two different RDA Axes, 1 and 3, respectively (Table 1, Fig. 4). MAP and MAT were only correlated with Axes 1 and $2(r=-0.80$ for the former and $r=-0.89$ for the latter), Consistent to our second hypothesis, the Gams-angle index provided a better metric than AETy and DEFy. AETy was correlated with both Axes 1 and 3 but with lower correlations coefficients than W GAMS and S ARID ( $\mathrm{r}=-0.54$ and -0.54 , respectively, Fig. $4 \mathrm{a}$ and $\mathrm{c}$ ). DEFy was primarily correlated with Axis $2(r=-0.76)$ and less with Axis $3(r=0.38$; Table 1 , Fig. 4a and c), as shown by the two climagrams of Fig. 6 where aridity zones delimited using DEFy were highly correlated with the vertical axis (growing season length, i.e., RDA axis 2), both in the dry- and wet-summer climagrams (Fig. 6a and b, respectively). Thus, the two three-dimention climagrams proposed here for western USA are conceptually very similar to the climagram proposed by Michalet (1991) for Morocco, with rainfall continentality distributed horizontally on the climagram, growing season length distributed vertically, and water balance distributed obliquely on the climagram.

\section{Discussion}

We found that rainfall continentality and summer water balance captured two different facets of plant stress. In agreement with our first hypothesis, across the entire breadth of climate we measured, rainfall continentality corresponded much better with vegetation distribution, and took priority over the length of the growing season and summer water balance. These results are of paramount importance, both for our understanding of the relationship between droughtrelated climate variables and plant physiology, and for predicting the ecological and evolutionary responses of plant species to changing climate.

Rainfall continentality and low water balance in the growing season, two different stresses for plants 
The rainfall continentality Gams index adjusted for winter precipitation (Pache et al., 1996a) was highly predictive of vegetation types - strongly separating those in the Pacific Coast Range, from woodlands and desert communities in the Intermountain Region and Rocky Mountains (see Daubenmire, 1946; Franklin \& Dyrness, 1973; Waring \& Franklin, 1979). These vegetation types are the foundation for classification in the western USA (Brown et al., 1998). This dramatic rainfall continentality gradient is induced by both a steep orographic effect on the winward sides of the coastal ranges and a strong rain shadow effect occurring on their leeward sides (Bach et al., 2013). Crucially, this continental/rain shadow-driven contrast is independent of the summer water balance contrast of the northwest temperate climate (wet summer) of western WA and OR to the south-western Mediterranean climate of CA (dry summer) and the south-east subtropical climate of AZ and NM (wet summer) to the desert Mediterreanean climate (dry summer) of the Mojave Desert in eastern CA and Great Basin in $\mathrm{NE}$ and eastern OR.

As noted, most correlations of vegetation distribution with climate in the western USA have used growing season or annual water balance indices such as AETy and DEFy (Stephenson, 1990; 1998). However, consistent to our second hypothesis these two metric, commonly used in biogeography to quantify drought stress, had a lower and more complex explanative power than W GAMS. We found that AETy was correlated with both Axes 1 and 3, and DEFy to Axis 2. This may be due to the sensitivity of AETy to winter and spring precipitation and to summer precipitation, with the former increasing AETy in oceanic climates and the latter decreasing AETy in Mediterranean climates (see Fig. 1). This explains why annual AETy does not capture key climate patterns (i.e., rainfall continentality and summer water balance) and the vegetation differences associated with it. The high correlation between DEFy and Axis 2 is due to the increase in precipitation and decrease in temperature with increasing altitude in mountain ranges, both contributing to decreasing DEFy, as also observed in the ombrothermal method (Bagnouls \& Gaussen, 1953; Walter \& Lieth, 1960). This latter result is also consistent with changes in aridity zones of Emberger (1930) and DEFy with increasing altitude in the climagram of Michalet (1991) for Morocco and the two climagrams for Western USA (Fig. 6), respectively. However, altitude has very large effects on temperature (Rolland, 2003). Thus, this is not easy to disentangle the effects on vegetation of DEFy and length of the growing season (Ozenda, 1985; Grace, 1987).

Tmin was also strongly correlated with RDA Axis 1 , which is consistent with the tight physical relationships between rainfall continentality, cloudiness, VPD and irradiance. 
Correspondingly, oceanic climates have high winter precipitation and high night temperatures in the winter (Waring \& Franklin, 1979; Bach et al., 2013). High VPD and irradiance associated with rainfall continentality have strong effects on canopy microclimate and leaf physiology (Michalet et al., 2003; Simonin et al., 2009; Novick et al., 2016). This facet of drought is not captured in the indices of soil water deficit during the growing season (Bagnouls \& Gaussen, 1953; Stephenson, 1990). The winter Gams-angle index is a highly effective way to capture this VPD-related component of drought.

Pache et al. (1996a) found that the geographical distribution of Albies alba in the European Alps was highly correlated with the W GAMS index, with no occurrence of this species in the most continental inner Central Alps. This is also the case for many Abies species in the Mediterranean Basin, which only occur in the hyper humid Mediterranean bioclimate characterized by high winter precipitation (Quezel \& Médail, 2003 and see Fig. 2). The common occurrence of North-American Abies species in the oceanic cluster groups in our study is consistent with results from Europe and the Mediterranean Basin. Interestingly, the two larch species in the study area, Larix occidentalis and L. lyalii, only occur in sites of intermediate continentality (cluster groups 12 and 16), whereas in Europe Larix decidua is common in the most continental inner zone of the European Alps. This may be due to the higher rainfall continentality in the Rocky Mountains (W GAMS is always lower than $70^{\circ}$ in the Alps, vs. often over $85^{\circ}$ in the Rocky Mountains; Pache et al., 1996a; see Fig. S3.3a in Appendix S3).

Another ecological pattern than distinguishes rainfall continentality from summer water balance is the relationship between the climatic distribution of tree species and their responses to neighbours when seedlings. In the European Alps, Saccone et al. (2009) reported that $A$. alba tolerated low summer water balance but not high air atmospheric stress (high VPD) due to rainfall continentality. In this context, $A$. alba was facilitated by adult canopies during the August 2003 European heat-wave. In contrast, Picea abies tolerated high irradiance due to continentality, but was intolerant to low summer water balance. In turn, this species was negatively affected by competition for water during the heat-wave. Similar results were found by Muhamed et al. (2013) and Guignabert et al. (2020) for Q. suber and Pinus pinaster, respectively, two Mediterranean species known for their oceanic distribution. In their experiments, seedlings of both species were facilitated by the shade of shrubs in gaps and forest dune communities from south-west France, correlated with lower VPD below shrubs despite lower soil water availability than where shrubs were experimentally removed. 
412 In the western USA, W GAMS values can be lower than $10^{\circ}$ along the Pacific coast and exceed $85^{\circ}$ in the eastern Rocky Mountains, whereas in the European Alps the lowest values are around $20^{\circ}$ in the north-west and the highest values below $70^{\circ}$ in the inner Central Alps (Pache et al., 1996a; Michalet, 2001). The very high level of rainfall continentality observed in California and Oregon, immediately to the east of the Sierra Nevada and Cascade Ranges, only $300 \mathrm{~km}$ from the Pacific Coast, has its only parallel in Europe at a distance of at least $3000 \mathrm{~km}$ from the Atlantic Ocean, in the Ukraine. In contrast, except in western Washington, summer water balance is very low in the western USA and thus varies much less spatially than in Europe. This may explain the much higher relative importance of rainfall continentality than summer water balance for vegetation distribution in western USA than in Europe (Bagnouls \& Gaussen, 1953). Additionally, the strong contrast existing along the Pacific coast between the high winter rainfall and low summer rainfall (see Fig. 3 b and d), and not in Europe along the Atlantic Ocean, may explain the rarity of deciduous tree species in western north-America as compared to Europe and eastern north-America (Waring \& Franklin, 1979). One of the two deciduous oaks of the Rocky mountains, Quercus gambelii, has been shown to occur in the southern Rockies but not the northern ones, because of the higher summer rainfall of the latter due to the the American monsoon originating from the gulf of Mexico (Neilson \& Wullstein, 1983).

Disentangling rainfall continentality from summer water balance for predicting responses to climate change

Disentangling rainfall continentality from low summer water balance is crucial for improving the accuracy of our predictions for the effects of climate change on species distributions. Our results indicate that many plant species, and in particular deep rooted woody species, in the western USA may respond differently to changes in winter vs. summer precipitation. Neilson $(1986,1987)$ have shown that past low-frequency variations in winter and summer rainfall and temperatures drove the spatial dynamic of C3 and C4 species in the Chihuahuan Desert. Our results also showed the ability of rainfall continentality to be strongly associated with subspecies formation, with the three most common conifer species of western USA (Pinus ponderosa, Pinus contorta and Pseudotsuga menziesii) represented by different subtaxons in oceanic and continental climates along RDA Axis 1. This supports Ikeda et al. (2017) who found that including genetically informed ecological niche models improved the accuracy of predictions of species distributions under climate change. Thus, if the future climate becomes 
drier in summer and thus more Mediterranean, or drier in winter and thus more continental, we might predict strikingly different responses among woody plant species and their subspecies. Most climate change studies have focused on summer, or growing season drought stress (Breda, Huc, Granier, \& Dreyer, 2006; Rehfeldt et al., 2006; Williams et al., 2020), even though recent studies also indicate a trend towards increasing winter precipitation, as in Scotland (UK) (Malby, Whyatt, Timmis, Wilby, \& Orr, 2007) and in western US deserts (Munson et al., 2013; Palmquist et al., 2016). Munson et al. (2013) have suggested that increasing winter precipitation in western deserts should favour shrubs over grasses, considering the current relative dominance of the former functional group in western deserts characterized by higher winter than summer precipitation (Paruelo \& Lauenroth, 1996; but see Grover \& Musick, 1990). In contrast, Palmquist et al. (2016) constructed models suggesting that the benefits of higher winter rainfall for shrubs induced by climate change should be overwhelmed by higher evaporative demand later in the growing season. Novick et al. (2016) estimated that soil moisture supply and atmospheric demand for water independently limit vegetation productivity and water use during periods of drought stress. The results of our study support their conclusion - conceptual and mathematical models that do not independently resolve VPD and soil moisture limitations (and thus rainfall continentality and low water balance) will not adequately capture the magnitude of ecosystem response to increasing climate stress. In conclusion, we argue that the Gams-angle index proposed here to disentangle water balance from rainfall continentality has exceptional potential for predicting species responses to climate change, as well as contribute to fundamental plant biogeography (Bell, Bradford, \& Lauentoth, 2014; Violle, Reich, Pacala, Enquist, \& Kattge, 2014; Stevens, Kling, Schwilk, Varner, \& Kane, 2020).

\section{References}

Bach, A. J., Price, L. W., Dorn, R., Liu, T., \& Phillips, F. (2013). Mountain Climate, Mountain Geography: Physical and Human Dimensions. University of California Press, Berkeley.

Bagnouls, F., \& Gaussen, H. (1953). Saison sèche et indice xérothermique. Bulletin de la Société d'Histoire Naturelles de Toulouse, 88, 193-239. 
Barbour, M., Loidi, J., Garcia-Baquero, G., Meyer, R., \& Whitworth V. (2014). The composition and physiognomy of forest types are strongly linked to distance inland along the northern California coast. Phytocoenologia, 44, 165-173. 10.1127/0340269X/2014/0044-0582

Bell, D. M., Bradford, J. B., \& Lauenroth, W. K. (2014). Early indicators of change: divergent climate envelopes between tree life stages imply range shifts in the western United States. Global Ecology and Biogeography, 23, 168-180. 10.1111/geb.12109

Breda, N., Huc, R., Granier, A., \& Dreyer, E. (2006). Temperate forest trees and stands under severe drought: a review of ecophysiological responses, adaptation processes and longterm consequences. Annals of Forest Sciences, 63, 625-644. 10.1051/forest:2006042

Brown, D. E., Reichenbacher, F., \& Franson, S. E. (1998). Classification of North American biotic communities. University of Utah Press, Salt Lake City.

Browning, K. A., \& Hill, F. F. (1981). Orographic rain. Weather, 36, 326-329.

Caccianiga, M., Andreis, C., Armiraglio, S., Leonelli, G., Pelfini, M., \& Sala, D. (2008). Climate continentality and treeline species distribution in the Alps. Plant Biosystems, 142, 66-78. 10.1080/11263500701872416

Daubenmire, R. F. (1946). The life zone problem in the north intermountain region. Northwest Science, 20, 2838.

del Moral, R., \& Watson, A. F. (1978). Gradient structure of forest vegetation in the central Washington Cascades. Vegetatio, 38, 29-48.

De Martonne, E. (1926). Aréisme et Indice d'aridité. Comptes Rendus Hebdomadaires des Séances de l'Académie des Sciences, Paris, 182, 1395-1398.

Desplanque, C., Rolland, C., \& Michalet, R. (1998). Dendroécologie comparée du sapin et de l'épicéa dans une vallée alpine française. Canadian Journal of Forest Research, 28, 737 748. 10.1139/cjfr-28-5-737

Dray, S., \& Dufour, A. B. (2007). The ade4 package: Implementing the duality diagram for ecologists. Journal of Statistical Software, 22, 1-20. 10.18637/jss.v022.i04

Dray, S., Chessel, D., \& Thioulouse, J. (2003). Co-inertia analysis and the linking of ecological data tables. Ecology, 84, 3078-3089. 10.1890/03-0178 
Emberger L., (1930). La végétation de la région méditerranéenne, essai d'une classification des groupements végétaux. Revue Générale de Botanique, 42, 641-662 et 705-721.

Fick, S. E., \& Hijmans, R. J. (2017). WorldClim 2: new 1-km spatial resolution climate surfaces for global land areas. International Journal of Climatology, 37, 4302-4315. doi:10.1002/joc.5086.

Frank, D. A., \& Inouye, R. S. (1994). Temporal variation in actual evapotranspiration of terrestrial ecosystems: patterns and ecological implications. Journal of Biogeography, 21, 401-411. 10.2307/2845758

Franklin, J. F., \& Dyrness, C. T. (1973). Natural vegetation of Oregon and Washington. USDA Forest Service Gen. Tech. Pacific Northwest Forest and Range Exper. Sta., Portland OR, Report PNW 8: 1417.

Gams, H. (1932). Die Klimatische Begrebzung von Pflanzenarealen und die Verteilung der hygrischen Kontinentalität in den Alpen. Zeitschrift der Geselchafften für Erkunde, 56-68, 178-198.

Grace, J. (1987). Climatic tolerance and the distribution of plants. New Phytologist, 106, $113-$ 130.

Grover, H. D., and Musick, B. (1990). Shrubland encroachment in southern New Mexico, U.S.A.: an analysis of desertification processes in the American Southwest. Climatic Change, 17, 305-330. 10.1007/BF00138373

Guignabert, A., Augusto, L., Gonzalez, M., Chipeaux, C., \& Delerue, F. (2020). Complex biotic interactions mediated by shrubs: revisiting the stress-gradient hypothesis and consequences for species survival. Journal of Applied Ecology, doi: 10.1111/13652664.13641

He, W., Zhang, B., Zhao, F., Zhang, S., Qi, W., Wang, J., \& Zhang, W. (2016). The Mass Elevation Effect of the Central Andes and Its Implications for the Southern Hemisphere's Highest Treeline. Mountain Research Development, 36, 213-221. 10.1659/MRDJOURNAL-D-15-00027

Ikeda, D. H., Max, T. L., Allan, G. J., Lau, M. K., Shuster, S. M., \& Whitham, T. G. (2017). Genetically informed ecological niche models improve climate change predictions. Global Change Biology, 23, 164-176. 10.1111/gcb.13470 
Jaccard, P. (1901). Etude de la distribution florale dans une portion des Alpes et du Jura. Bulletin de la Société Vaudoise des Sciences Naturelles, 37, 547-579.

Kaufman, L. \& Rousseeuw, P. J. (2009). Finding groups in data: an introduction to cluster analysis. Vol. 344. John Wiley \& Sons.

Maechler, M., Rousseeuw, P., Struyf, A., Hubert, M., \& Hornik, K. (2019). Cluster: Cluster Analysis Basics and Extensions. R package version 2.0.8.

Malby, A. R., Whyatt, J. A., Timmis, R. J., Wilby, R. L., \& Orr, H. G. (2007). Long-term variations in orographic rainfall: analysis and implications for upland catchments. Hydrological Sciences Journal, 52, 276-291. 10.1623/hysj.52.2.276

Manuel, N., Cornic, G., Aubert, S., Choler, P., Bligny, R., \& Heber, U. (1999). Protection against photoinhibition in the alpine plant Geum montanum. Oecologia, 119, 149-158. $10.1007 / \mathrm{s} 004420050771$

Michalet, R. (1991). Nouvelle synthèse bioclimatique des milieux méditerranéens. Application au Maroc septentrional. Revue d'Ecologie Alpine, 1, 45-60.

Michalet, R., Rolland, C., Joud, D., Gafta, D., \& Callaway, R. M. (2003). Associations between canopy and understory species increase along a rainshadow gradient in the Alps: habitat heterogeneity or facilitation? Plant Ecology, 165, 140-160. 10.1023/A:1022297624381

Miller, D. A., \& White, R. A. (1998). A Conterminous United States Multi-Layer Soil Characteristics Data Set for Regional Climate and Hydrology Modeling. Earth Interactions, 2. [Available on-line at http://EarthInteractions.org]

Muhamed, H., Le Bagousse-Pinguet, Y., Touzard, B., \& Michalet, R. (2013). The role of biotic interactions for the early establishment of oak seedlings in coastal dune forest communities? Forest Ecology \& Management, 297, 67-74. 10.1016/j.foreco.2013.02.023

Munson, S. M., Muldavin, E. H., Belnap, J., Peters, D. P. C., Anderson, J. P., Reiser, M. H., ... Christiansen, T. A. (2013). Regional signatures of plant response to drought and elevated temperature across a desert ecosystem. Ecology, 94, 2030-2041. 10.1890/121586.1

Neilson, R. P. (1986). High-Resolution Climatic Analysis and Southwest Biogeography. Science, 232, 27-34. 10.1126/science.232.4746.27 
Neilson, R. P. (1987). Biotic regionalization and climatic controls in western North America. Vegetatio, 70, 135-147.

Neilson, R. P., \& Wullstein, L. H. (1983). Biogeography of Two Southwest American Oaks in Relation to Atmospheric Dynamics. Journal of Biogeography, 10, 275-297. $10.2307 / 2844738$

Novick, K. A., Ficklin, D. L., Stoy, P. C., Williams, C. A., Bohrer, G., Oishi, A. C., ... Phillips, R. P. (2016). The increasing importance of atmospheric demand for ecosystem water and carbonfluxes. Nature Climate Change, 6, 1023-1027. 10.1038/NCLIMATE3114

Ozenda, P. (1985). La végétation de la chaîne alpine dans l'espace montagnard européen. Masson, Paris.

Pache, G., Michalet, R., \& Aimé, S. (1996a). A seasonal application of the Gams (1932) method, modified Michalet (1991): The example of the distribution of some important forest species in the Alpine chain. Dissertation Botanicae, 258, 31-54.

Pache, G., Aimé, S., \& Michalet, R. (1996b). A simple model for the study of the altitudinal rainfall gradient, applied in the Tyrolian orographic complex. Revue d'Ecologie Alpine, 3, 13-20.

Palmquist, K. A., Schlaepfer, D. R., Bradford, J. B., \& Lauenroth, W. K. (2016). Mid-latitude shrub steppe plant communities: climate change consequences for soil water resources. Ecology, 97, 2342-2354. 10.1002/ecy.1457

Paruelo, J. M., \& Lauenroth, W.K. (1996). Relative abundance of plant functional types in grasslands and shrublands of North America. Ecological Applications, 6, 1212-1224. $10.2307 / 2269602$

Peyre, C. (1983). Etagement de la végétation et gradients climatiques dans le système atlasique marocain. Le bassin de l'Oued Rdat et le versant sud de l'Atlas au méridien du Tizi N'Tichka. Bullutein de la Faculté des Sciences, Sciences de la Vie, Marrakech, 2, 87139.

Quézel, P., \& Médail F. (2003). Ecologie et biogéographie des forêts du bassin méditerranéen. Elsevier, Paris.R Core Team (2017).

R: A language and environment for statistical computing. R Foundation for Statistical Computing, Vienna, Austria. URL https://www.R-project.org/. 
593

594

595

596

597

598

599

600

601

602

603

604

605

606

607

608

609

610

611

612

613

614

615

616

617

618

619

620

Rehfeldt, G. E., Crookston, N. L., Warwell, M. V., \& Evans, J. S. (2006). Empirical analyses of plant-climate relationships for the western United States. International Journal of Plant Sciences, 167, 1123-1150. 10.1086/507711

Reinhardt, K., McAbee, K., \& Germino, M. J. (2019). Changes in structure and physiological functioning due to experimentally enhanced precipitation seasonality in a widespread shrub species. Plant Ecology, 220, 199-211. 10.1007/s11258-018-0845-z

Roe, G. H. (2005). Orographic precipitation. Annual Review of Earth and Planetary Sciences, 33, 645-671. 10.1146/annurev.earth.33.092203.122541

Rolland, C. (2003). Spatial and Seasonal Variations of Air Temperature Lapse Rates in Alpine Regions. Journal of Climate, 16, 1032-1046. 10.1175/15200442(2003)016<1032:SASVOA>2.0.CO;2

Rueda, M., Godoy, O., \& Hawkins, B. A. (2018). Trait syndromes among North American trees are evolutionarily conserved and show adaptive value over broad geographic scales. Ecography, 41, 540-550. 10.1111/ecog.03008

Saccone, P., Pagès, J. P., Delzon, S., Brun, J. J., \& Michalet, R. (2009). The role of biotic interactions in altering tree seedling responses to an extreme climatic event. Journal of Vegetation Science, 20, 403-414. 10.1111/j.1654-1103.2009.01012.x

Schermerhorn, V. P. (1967). Relations between topography and annual precipitation in Western Oregon and Washington. Water Resources Research, 3, 707-711. 10.1029/WR003i003p00707

Simonin, K. A., Santiago, L. S., \& Dawson, T. E. (2009). Fog interception by Sequoia sempervirens (D. Don) crowns decouples physiology from soil water deficit. Plant Cell Environment, 32, 882-892. 10.1111/j.1365-3040.2009.01967.x

Stephenson, N. L. (1990). Climatic Control of Vegetation Distribution - the Role of the Water-Balance. American Naturalist, 135, 649-670. 10.1086/285067

Stephenson, N. L. (1998). Actual evapotranspiration and deficit: biologically meaningful correlates of vegetation distribution across spatial scales. Journal of Biogeography, 25, 855-870. 10.1046/j.1365-2699.1998.00233.x 
Stevens, J. T., Kling, M. M., Schwilk, D. W., Varner, J. M., \& Kane, J. M. (2020). Biogeography of fire regimes in western US conifer forests: A trait-based approach." Global Ecology and Biogeography, 29, 944-955. 10.1111/geb.13079

Violle, C., Reich, P. B., Pacala, S. W., Enquist, B. J., \& Kattge, J. (2014). The emergence and promise of functional biogeography. Proceedings of the National Academy of Sciences USA, 111, 13690-13696. 10.1073/pnas.14154 42111

Walter, H., \& Lieth, H. (1960). Klimadiagramm Weltatlas. G. Fischer, Jena.

Waring, R. H., \& Franklin, J. F. (1979). Evergreen forests of the Pacific Northwest. Science, 4400, 1380-1386. 10.1126/science.204.4400.1380

Waring, R. H., Emmingham, W. H., Gholz, H. L., \& Grier, C. C. (1978). Variation in maximum leaf area of coniferous forests in Oregon and its ecoogical significance. Forests, 24, 131-140.

Williams, A. P., Cook, E. R., Smerdon, J. E., Cook, B. I., Abatzoglou, J. T., Bolles, K., ... Livneh, B. (2020). Large contribution from anthropogenic warming to an emerging North American megadrought. Science, 368, 314-318. 10.1126/science.aaz9600

\section{Data accessibility statement}

Data will available on Dryad (doi:10.5061/dryad.dbrv15f06)

https://datadryad.org/stash/dataset/doi:10.5061/dryad.dbrv15f06. 
640 Table 1: Regression coefficients of the five variables of the RDA for the three axes and post-

641 RDA correlations of the variables extracted from Worldclim with RDA scores. $* *:<0.01$,

$\begin{array}{lccc} & \text { RDA Axis 1 } & \text { RDA Axis 2 } & \text { RDA Axis 3 } \\ \text { w.GAMS } & 0.99 * * * & -0.06 & 0.05 \\ \text { w.PREC } & -0.87 * * * & 0.12^{* *} & -0.01 \\ \text { Tmin } & -0.63 * * * & -0.72^{* * *} & 0.18^{* * *} \\ \text { GSL } & -0.33^{* * *} & -0.87^{* * *} & 0.14^{* *} \\ \text { S.ARID } & 0.07 & 0.27 * * * & -0.86^{* * *} \\ & & & \\ \text { MAT } & -0.22 * * * & -0.89 * * * & 0.22^{* * *} \\ \text { MAP } & -0.80^{* * *} & 0.19^{* * *} & -0.18^{* * *} \\ \text { AETy } & -0.54 * * * & 0.30^{* * *} & -0.54^{* * *} \\ \text { DEFy } & 0.30^{* * *} & -0.76^{* * *} & 0.38^{* * *}\end{array}$

644 Table 2: Vegetation labels, dominant species, continentality (position on RDA Axis 1, Fig.

645 S3.3a), locations and vegetation zones (position on RDA Axis 2, Fig. S3.3b) of the 16 cluster 646 groups. Vegetation zones correspond to GSL: high tropical: 10 months, low subtropical: 9 m., 647 high subtropical: $8 \mathrm{~m}$., low temperate: $7 \mathrm{~m}$., high temperate: $6 \mathrm{~m}$., boreal: $5 \mathrm{~m}$. Abbreviations: 648 Rocky Mt. = Rocky Mountains, Pseudotsuga menziesii $m$. or g. = Pseudotsuga menziesii var. menziesii or 649 var. glauca, Pinus ponderosa p. or s. = Pinus ponderosa var. ponderosa or var. scopulorum.

\begin{tabular}{|c|c|c|c|c|}
\hline $\begin{array}{l}\text { Cluster } \\
\text { groups }\end{array}$ & $\begin{array}{l}\text { Label } \\
\text { Vegetation }\end{array}$ & $\begin{array}{l}\text { Dominant } \\
\text { Species }\end{array}$ & $\begin{array}{l}\text { Continentality } \\
\text { Location }\end{array}$ & $\begin{array}{l}\text { Vegetation } \\
\text { zone }\end{array}$ \\
\hline $\begin{array}{c}11 \\
-\end{array}$ & $\begin{array}{l}\text { Californian evergreen } \\
\text { oak forests }\end{array}$ & $\begin{array}{l}\text { Quercus agrifolia, Q. douglasii, } \\
\text { Q. wislizenii, Q. kellogii. Q. chrysolepis }\end{array}$ & $\begin{array}{l}\text { Oceanic } \\
\text { CA, OR }\end{array}$ & $\begin{array}{l}\text { High subtropical } \\
\text { and low temperate }\end{array}$ \\
\hline $\begin{array}{l}1 \\
-\end{array}$ & $\begin{array}{l}\text { Coastal rain } \\
\text { temperate forests }\end{array}$ & $\begin{array}{l}\text { Pseudotsuga menziesii m., } \\
\text { Thuya plicata, Tsuga heterophylla }\end{array}$ & $\begin{array}{l}\text { Oceanic } \\
\text { WA, OR, CA }\end{array}$ & $\begin{array}{l}\text { Low and } \\
\text { high temperate }\end{array}$ \\
\hline $\begin{array}{l}8 \\
-\end{array}$ & $\begin{array}{l}\text { Southern California } \\
\text { Chaparral }\end{array}$ & $\begin{array}{l}\text { Quercus agrifolia, Q. douglasii, Ceanothus sp. } \\
\text { Pseudotsuga macrocarpa }\end{array}$ & $\begin{array}{l}\text { Intermediate } \\
\text { CA }\end{array}$ & $\begin{array}{l}\text { Low and high } \\
\text { subtropical }\end{array}$ \\
\hline $\begin{array}{r}12 \\
-\end{array}$ & $\begin{array}{l}\text { Northwestern Rocky Mt. } \\
\text { subalpine forests }\end{array}$ & $\begin{array}{l}\text { Thuya plicata, Abies grandis, Pinus monticola } \\
\text { Pseudotsuga menziesii g., Larix occidentalis }\end{array}$ & $\begin{array}{l}\text { Intermediate } \\
\text { ID, MT }\end{array}$ & $\begin{array}{l}\text { High temperate } \\
\text { and boreal }\end{array}$ \\
\hline $\begin{array}{c}16 \\
-\end{array}$ & $\begin{array}{l}\text { North western Rocky Mt. } \\
\text { mountain forests }\end{array}$ & $\begin{array}{l}\text { Pseudotsuga menziesii g., } \\
\text { Larix occidentalis, Pinus ponderosa } p .\end{array}$ & $\begin{array}{l}\text { Intermediate } \\
\text { MT, WA, ID }\end{array}$ & High temperate \\
\hline $\begin{array}{l}4 \\
-\end{array}$ & Sonoran desert & $\begin{array}{l}\text { Cercidium microphyllum, Olneya tesota, } \\
\text { Prosopis velutina, Opuntia sp. }\end{array}$ & $\begin{array}{l}\text { Continental } \\
\mathrm{AZ}\end{array}$ & $\begin{array}{l}\text { High tropical } \\
\text { and low subtropical }\end{array}$ \\
\hline $\begin{array}{l}5 \\
-\end{array}$ & $\begin{array}{l}\text { Eastern evergreen } \\
\text { oak woodlands }\end{array}$ & $\begin{array}{l}\text { Quercus emoryi, Q. arizonica, } \\
\text { Yucca sp., Agave sp. }\end{array}$ & $\begin{array}{l}\text { Continental } \\
\mathrm{NM}, \mathrm{AZ}\end{array}$ & $\begin{array}{l}\text { Low and high } \\
\text { subtropical }\end{array}$ \\
\hline $\begin{array}{c}14 \\
-\end{array}$ & Mojave Desert & $\begin{array}{l}\text { Larrea tridentata, Ambrosia dumosa, } \\
\text { Yucca brevifolia, Y. shedigera }\end{array}$ & $\begin{array}{l}\text { Continental } \\
\text { CA, NM, UT }\end{array}$ & $\begin{array}{l}\text { Low and high } \\
\text { subtropical }\end{array}$ \\
\hline $\begin{array}{l}10 \\
-\end{array}$ & $\begin{array}{l}\text { Rocky Mt. pinion- } \\
\text { juniper woodlands }\end{array}$ & $\begin{array}{l}\text { Pinus edulis, Juniperus osteosperma, } \\
\text { Quercus gambelii, Artemisia tridentata }\end{array}$ & $\begin{array}{l}\text { Continental } \\
\text { UT, NM, CO, AZ }\end{array}$ & $\begin{array}{l}\text { High subtropical } \\
\text { and low temperate }\end{array}$ \\
\hline
\end{tabular}




\begin{tabular}{|c|c|c|c|c|}
\hline $\begin{array}{l}3 \\
-\end{array}$ & $\begin{array}{l}\text { Great Basin pinion- } \\
\text { juniper woodlands }\end{array}$ & $\begin{array}{l}\text { Pinus monophylla, Juniperus osteosperma, } \\
\text { Artemisia tridentata }\end{array}$ & $\begin{array}{l}\text { Continental } \\
\text { UT, NV, WY, CA }\end{array}$ & Low temperate \\
\hline $\begin{array}{l}2 \\
-\end{array}$ & $\begin{array}{l}\text { Great Basin } \\
\text { mountain woodlands }\end{array}$ & $\begin{array}{l}\text { Pinus ponderosa p., Juniperus occidentalis, } \\
\text { Artemisia tridentata, }\end{array}$ & $\begin{array}{l}\text { Continental } \\
\text { CA, OR, NM, ID }\end{array}$ & $\begin{array}{l}\text { Low and high } \\
\text { temperate }\end{array}$ \\
\hline $\begin{array}{l}13 \\
-\end{array}$ & $\begin{array}{l}\text { Northeastern } \\
\text { mountain woodlands }\end{array}$ & $\begin{array}{l}\text { Pinus ponderosa s., Juniperus scopulorum, } \\
\text { Artemisia frigida, A. cana }\end{array}$ & $\begin{array}{l}\text { Continental } \\
\text { MT, WY }\end{array}$ & $\begin{array}{l}\text { Low and } \\
\text { high temperate }\end{array}$ \\
\hline $\begin{array}{l}15 \\
-\end{array}$ & $\begin{array}{l}\text { Great Basin } \\
\text { sagebrush steppe }\end{array}$ & $\begin{array}{l}\text { Artemisia tridentata, } \\
\text { Chrysothamnus nauseasus }\end{array}$ & $\begin{array}{l}\text { Continental } \\
\text { ID, OR, WA }\end{array}$ & $\begin{array}{l}\text { Low and high } \\
\text { temperate }\end{array}$ \\
\hline $\begin{array}{l}6 \\
-\end{array}$ & $\begin{array}{l}\text { North eastern } \\
\text { Rocky Mt. woodlands }\end{array}$ & $\begin{array}{l}\text { Pseutsuga menziesii g., P. flexilis, } \\
\text { Artemisia tridentata, Juniperus scopulorum }\end{array}$ & $\begin{array}{l}\text { Continental } \\
\text { MT, WY, CO, ID }\end{array}$ & $\begin{array}{l}\text { Low and } \\
\text { high temperate }\end{array}$ \\
\hline $\begin{array}{l}7 \\
-\end{array}$ & $\begin{array}{l}\text { Southern Rocky Mt. } \\
\text { mountain forests }\end{array}$ & $\begin{array}{l}\text { Pinus ponderosa s., Pseudotsuga menziesii g., } \\
\text { Picea pungens, Abies concolor }\end{array}$ & $\begin{array}{l}\text { Continental } \\
\mathrm{NM}, \mathrm{CO}, \mathrm{AZ}\end{array}$ & High temperate \\
\hline $\begin{array}{l}9 \\
-\end{array}$ & $\begin{array}{l}\text { Eastern Rocky Mt. } \\
\text { subalpine forests }\end{array}$ & $\begin{array}{l}\text { Abies lasiocarpa, Picea engelmanii, } \\
\text { Pseudotsuga menziesii g., Pinus contorta }\end{array}$ & $\begin{array}{l}\text { Continental } \\
\text { MT, WY, CO }\end{array}$ & Boreal \\
\hline
\end{tabular}


(a)

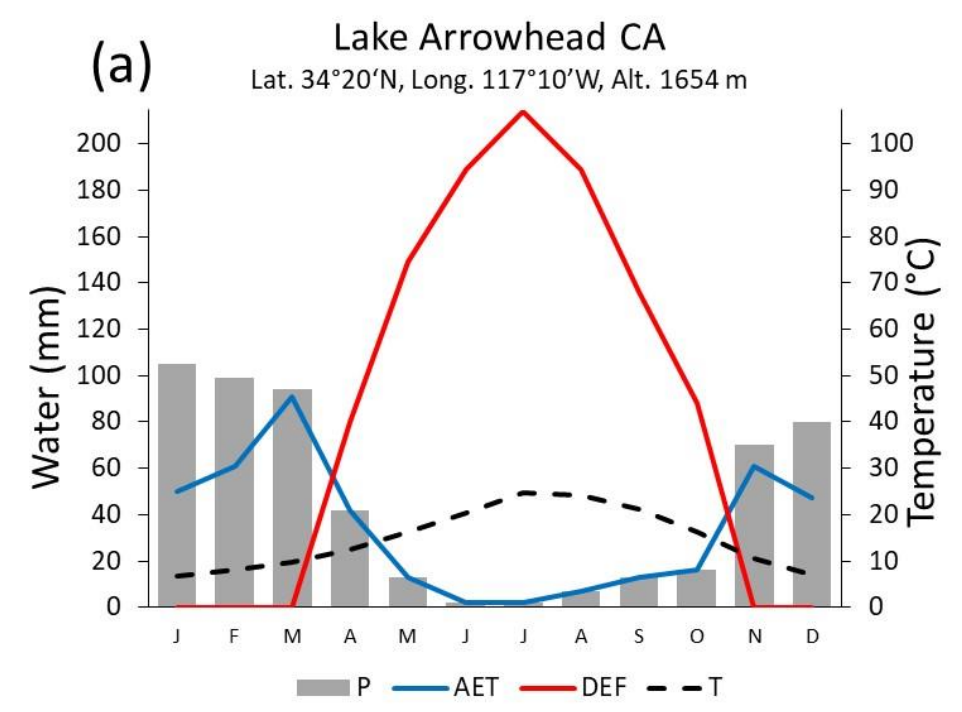

(b)

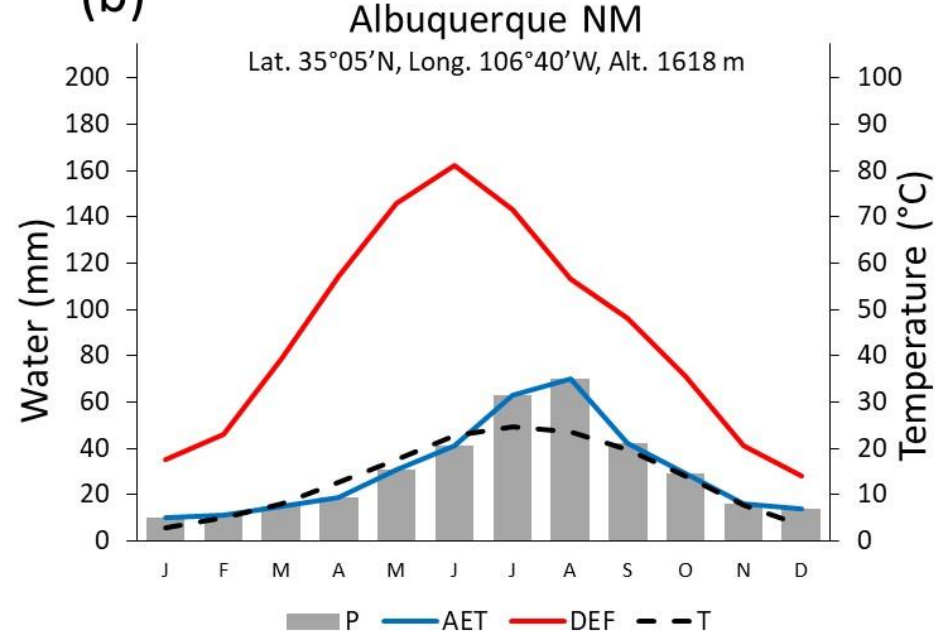

660 (c)

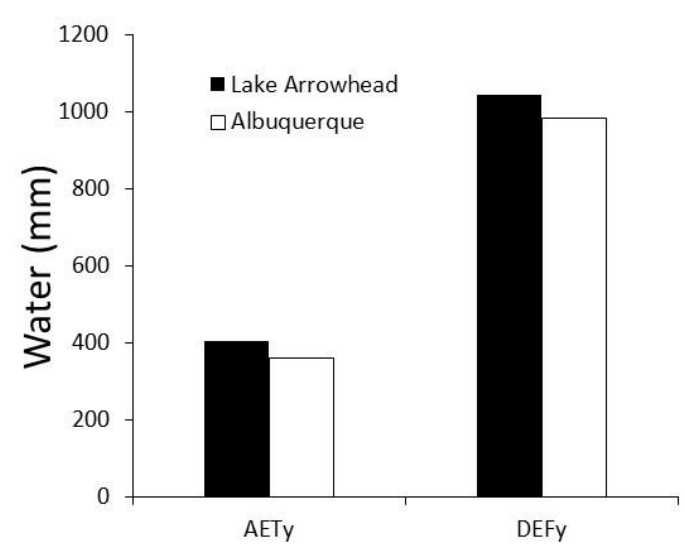

(d)

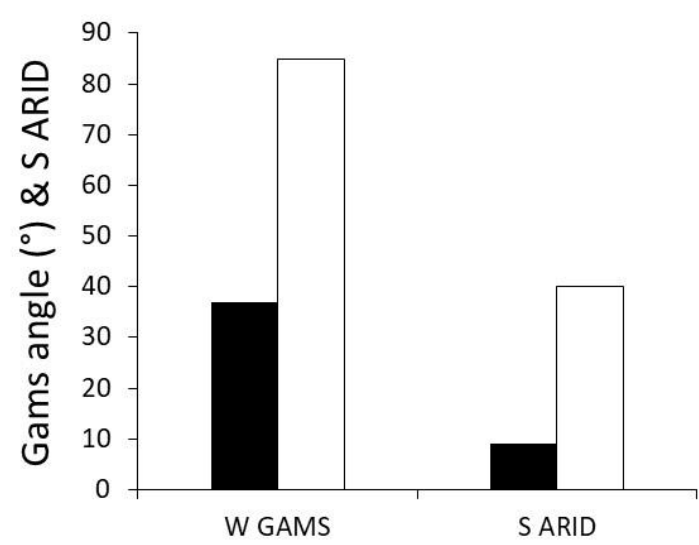

Fig. 1: Left: ombrothermal diagrams and actual evapotranspiration (AET) and deficit (DEF) from similar latitude and altitude. Right panels show that annual AET (AETy) and DEF (DEFy) (c) are very similar, although rainfall continentality (W GAMS) and summer water balance (S ARID) (d) are very different. Note that the vegetation of stations (a) and (b) were classified in cluster 11 and 5 in Table 2, i.e., CA evergreen oaks and eastern evergreen oak woodlands, respectively. 
Fig. 2: Distribution of oceanic (in blue, from high to low altitude Abies pinsapo ssp. Moroccana in the picture and Quercus canariensis, Quercus suber and Quercus coccifera), semi-oceanic (in green, from high low altitude Cedrus atlantica, Quercus rotundifolia in the picture and Tetraclinis articulata) and continental species (in red, from high to low altitude Juniperus thurifera in the picture, Juniperus phoenicea and Stipa tenacissima) from Morocco within the climagram of Michalet (1991). The climagram includes a horizontal axis for the rainfall continentality gradient quantified with the annual Gams angle index (driving VPD and cold stresses), a vertical axis for the altitudinal gradient (driving the length of the growing season) and, in an oblique dimension, the water balance gradient calculated with the Emberger index (1930). The latter was inspired by the De Martonne (1926) aridity index and is primarily based on the ratio of annual precipitation to mean temperature. Coloured frames along the horizontal axis represent the different zones of continentality delimited using the annual Gams angle index and oblique plain white lines along the vertical axis delimit the vegetation belts in relation to altitude and latitude (see also legend of Table 2 for GSL). Oblique dashed lines delimit the aridity zones of Emberger (1930) indicated with white frames.

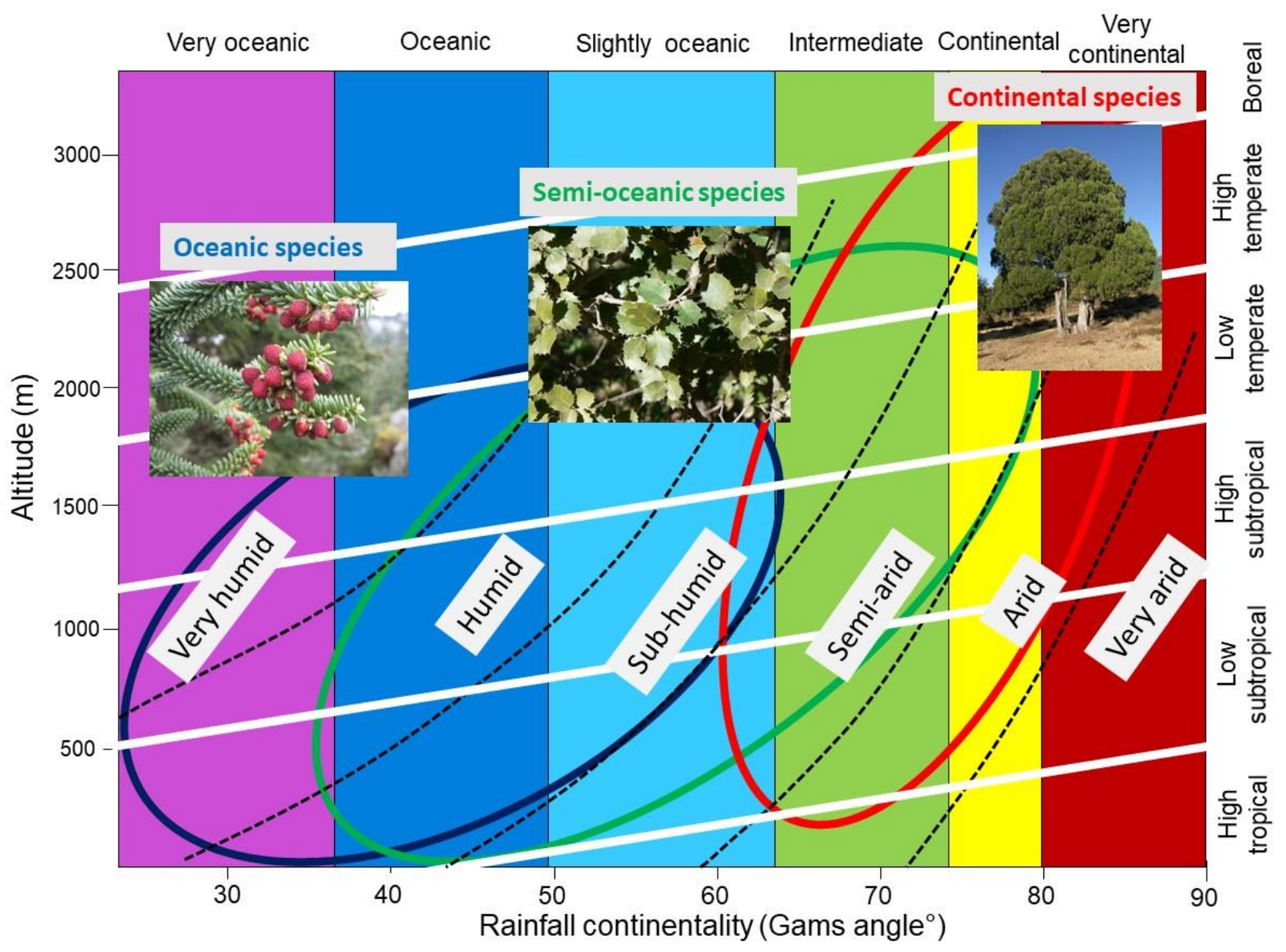


Fig. 3: Location of our 467 plots and 16 cluster groups in the 11 states of western USA (a), and maps of W GAMS index (b), Tmin (c) and Summer Aridity (d). Color legends of symbols of cluster groups are in Fig. 4. Abbreviations: AZ: Arizona, CA: California, CO: Colorado, ID: Idaho, MT: Montana, NE: Nevada, NM: New Mexico, OR: Oregon, UT: Utah, WA: Washington State, WY: Wyoming.

(a)

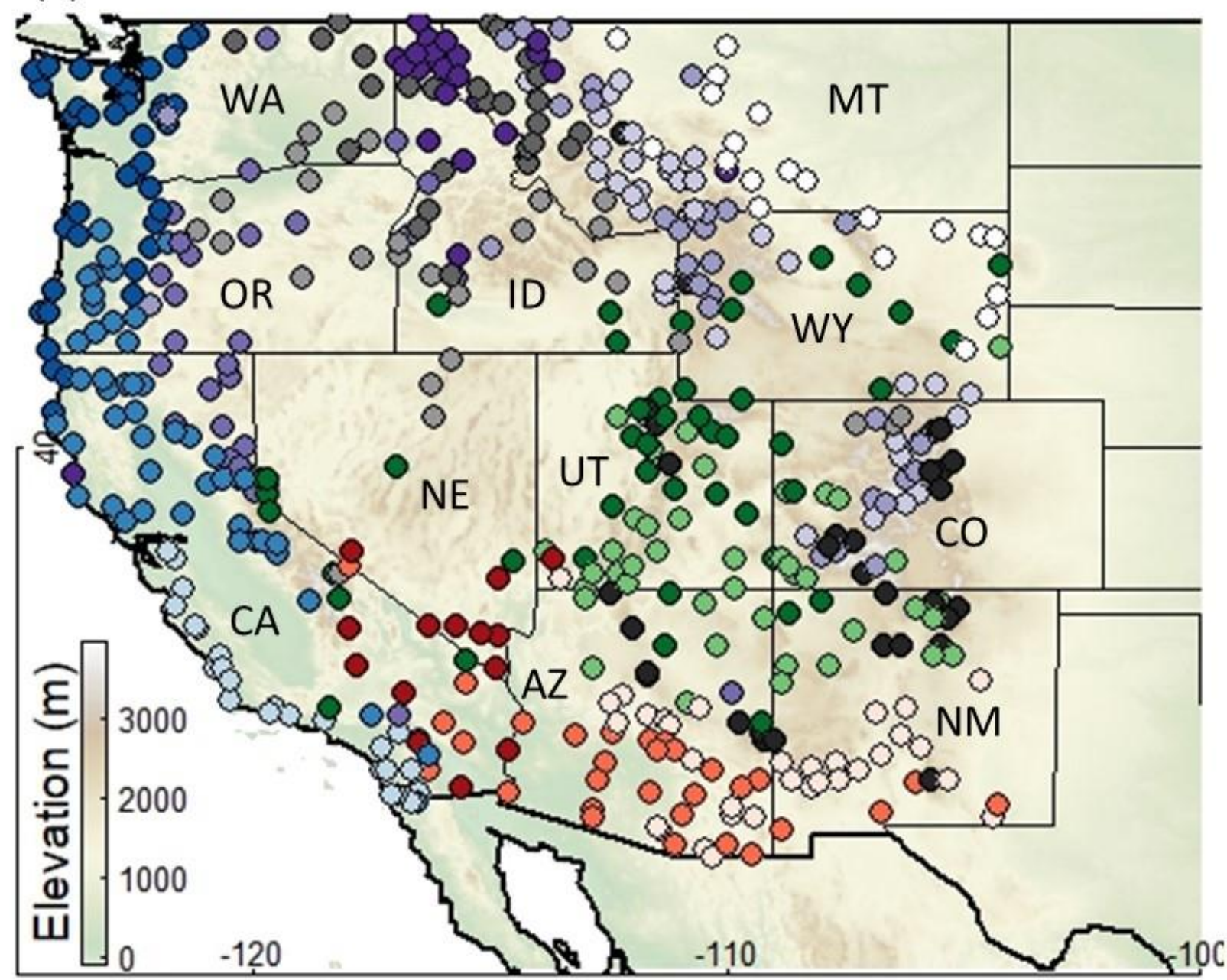

(b)
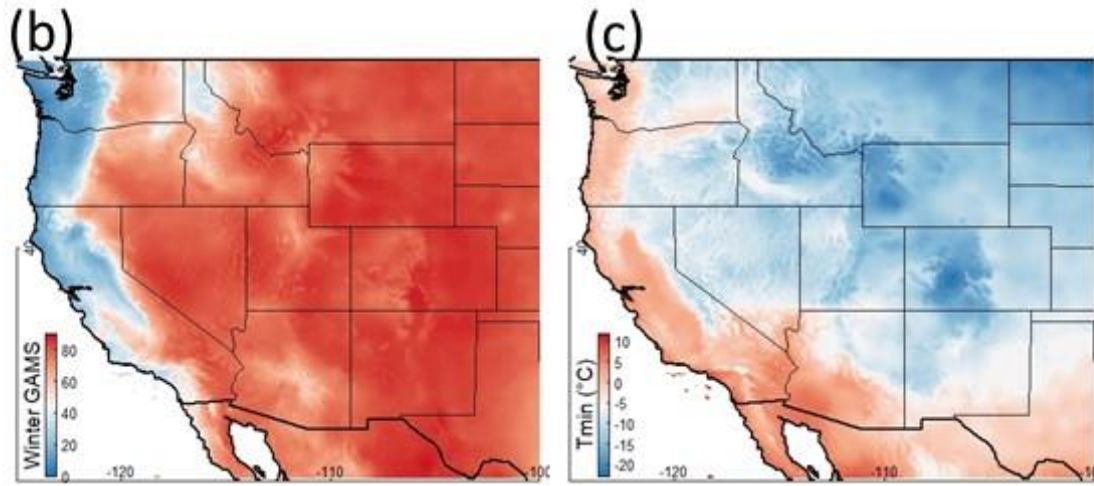

(d)

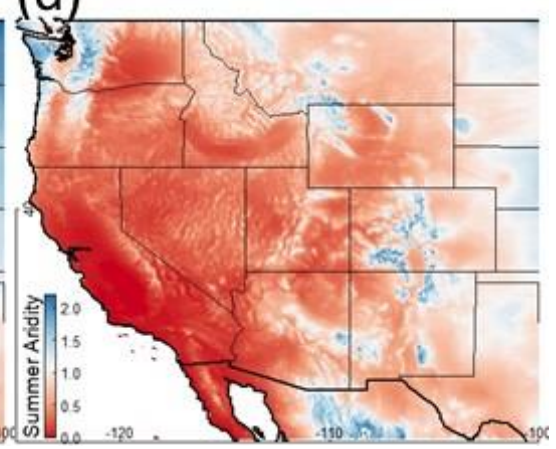


Fig. 4: RDA results, with in (a) 1-2 diagram for climate variables and in (b) for mean scores $( \pm 1 \mathrm{SE})$ of the 16 cluster groups, and in (c) 1-3 diagram for climate variables and in (d) for mean scores ( $\pm 1 \mathrm{SE}$ ) of the 16 cluster groups. Dashed arrows in panels (a) and (c) show correlations for supplementary variables not included in the RDA.

(a)
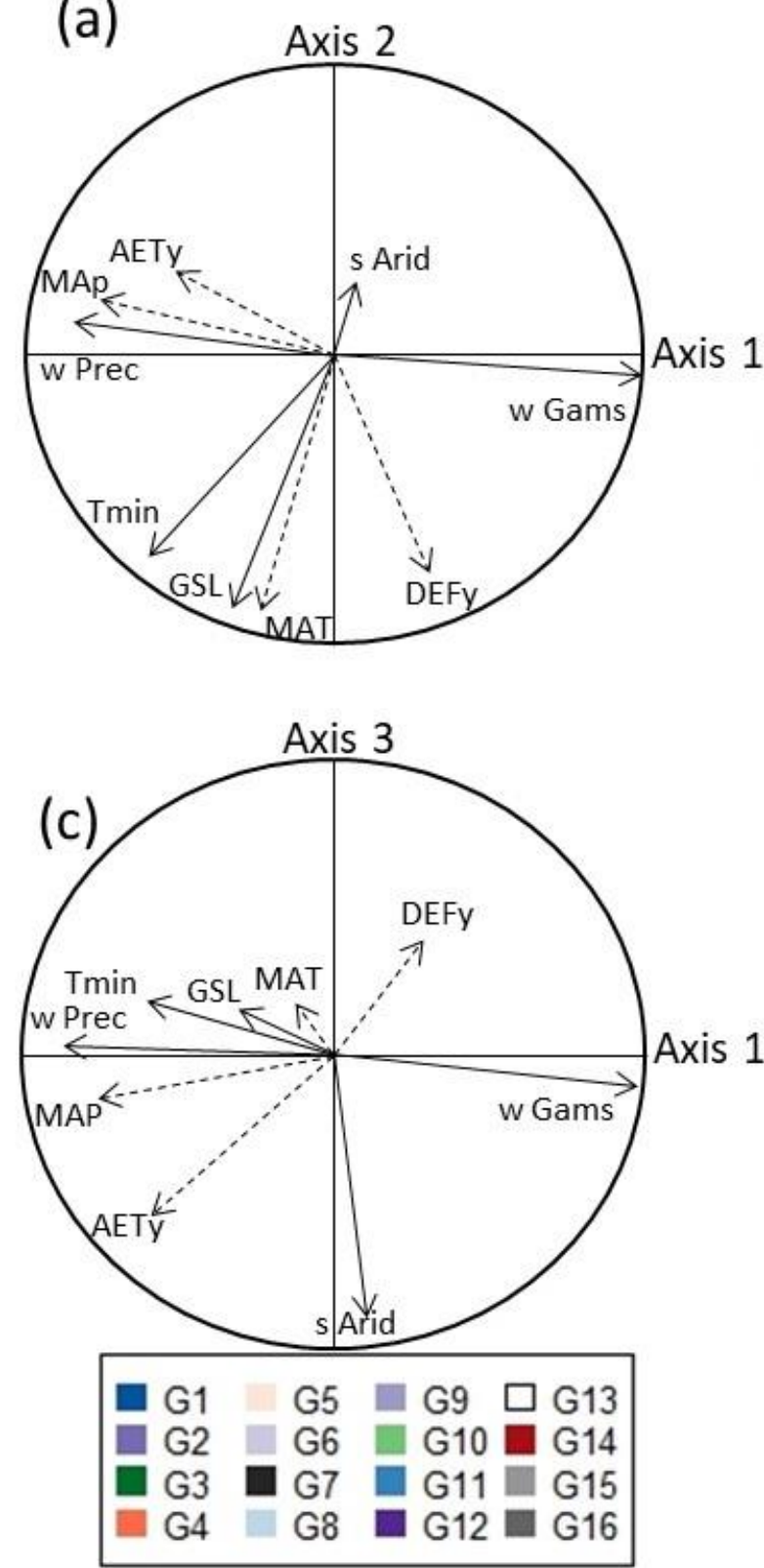

(b)

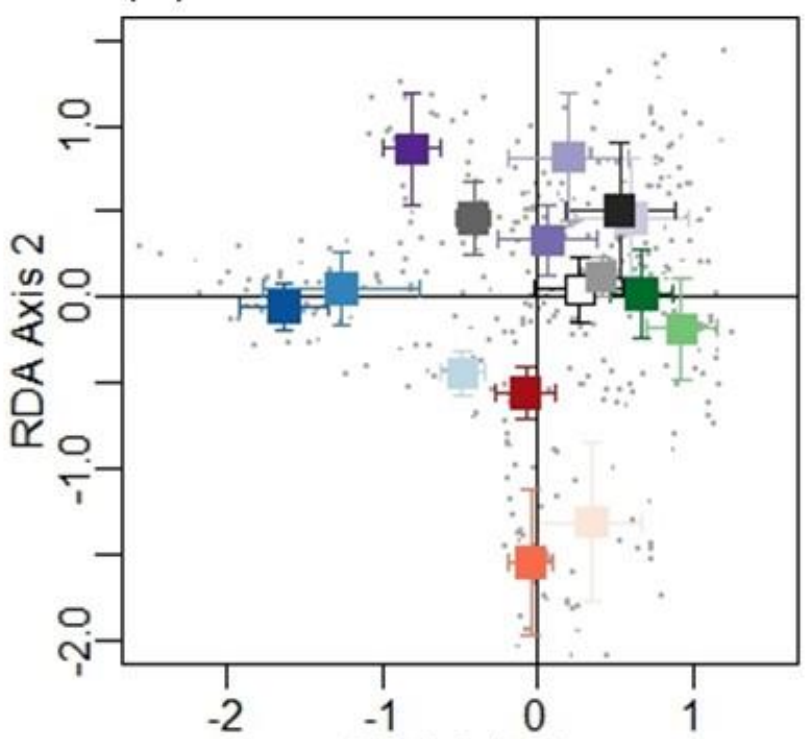

(d)

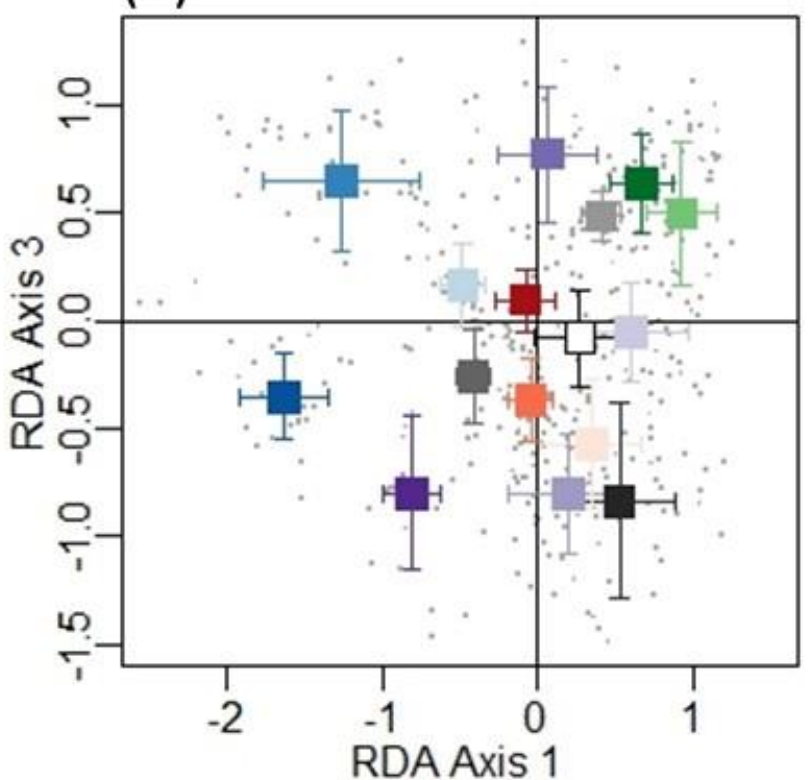


Fig. 5: Relationships between Tmin and W GAMS (a) and S ARID and W GAMS (b) for the 467 plots (black dots) and Worldclim datas (grey clouds).

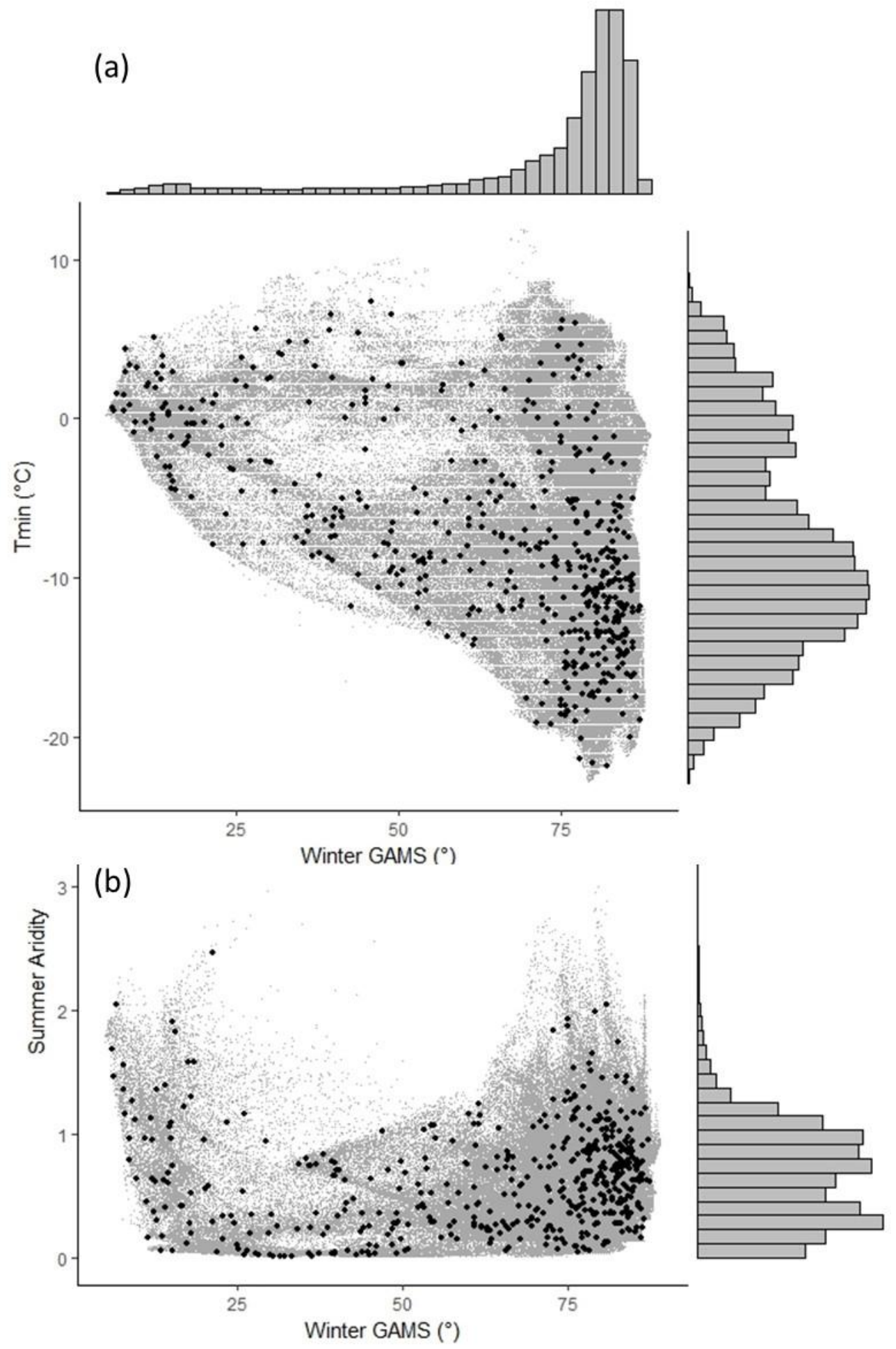


692

693

694

695

696

697

698

699

Fig. 6: Mean ( $\pm 1 \mathrm{SE}$ ) positions of cluster groups from (a) dry-summer (upper part of RDA axis 3, Fig. 3d) and (b) wet-summer sites (lower part of RDA axis 3, Fig. 3d) along the rainfall continentality and growing-season length gradients. Ellipses delimit the positions of sites with increasing DEFy following Stephenson (1998), with in blue humid (DEFy 38-200), green sub-humid (DEFy 201-640), yellow semi-arid (DEFy 640-820) and red arid sites (DEFy 821-1770). Legends of cluster groups are indicated by their numbers and colours (see Fig. 4). Continentality zones are indicated below the horizontal axis and vegetation belts along the vertical axis (and see Table 2 for their delimitations).

(a)

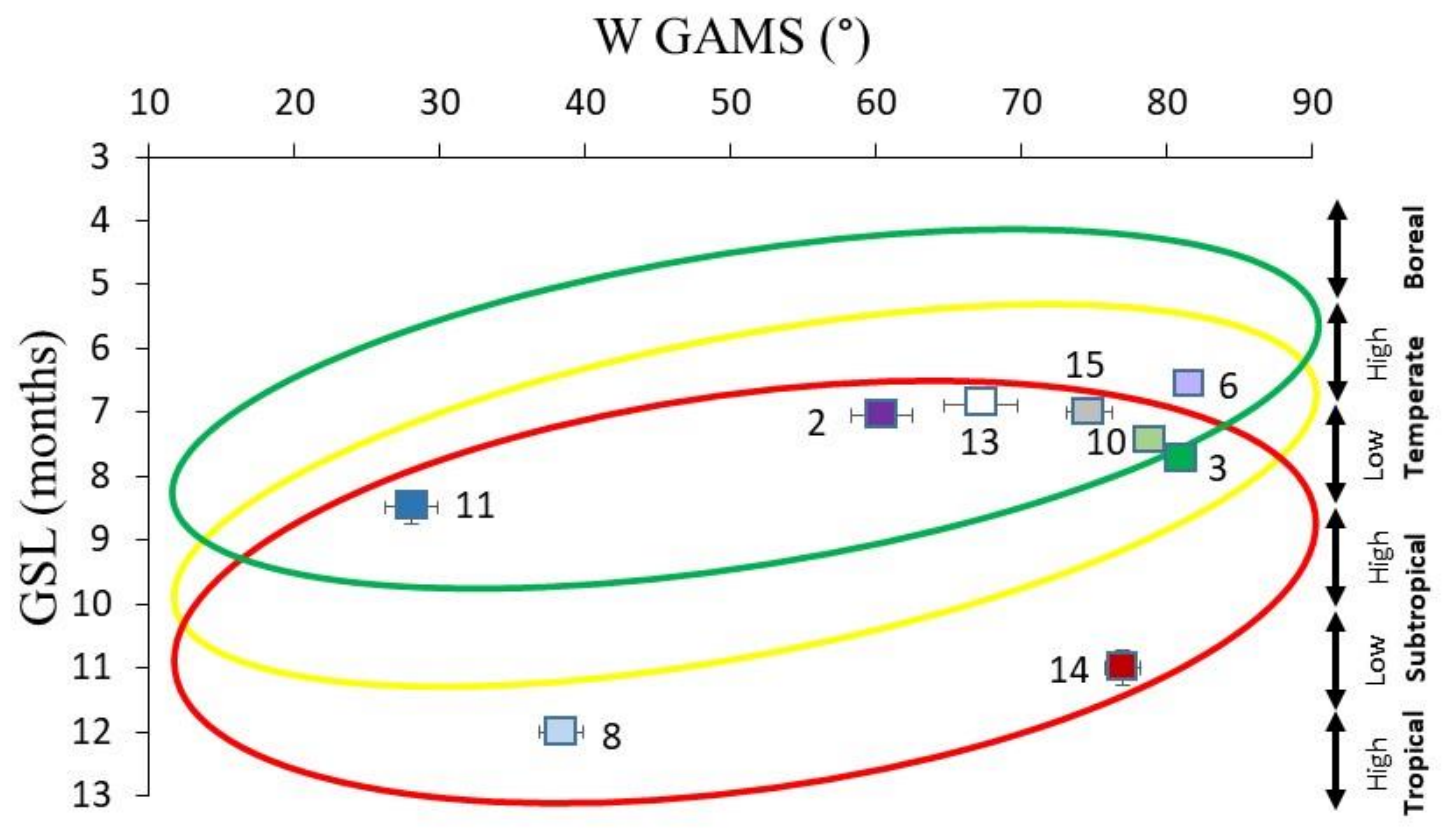

(b)

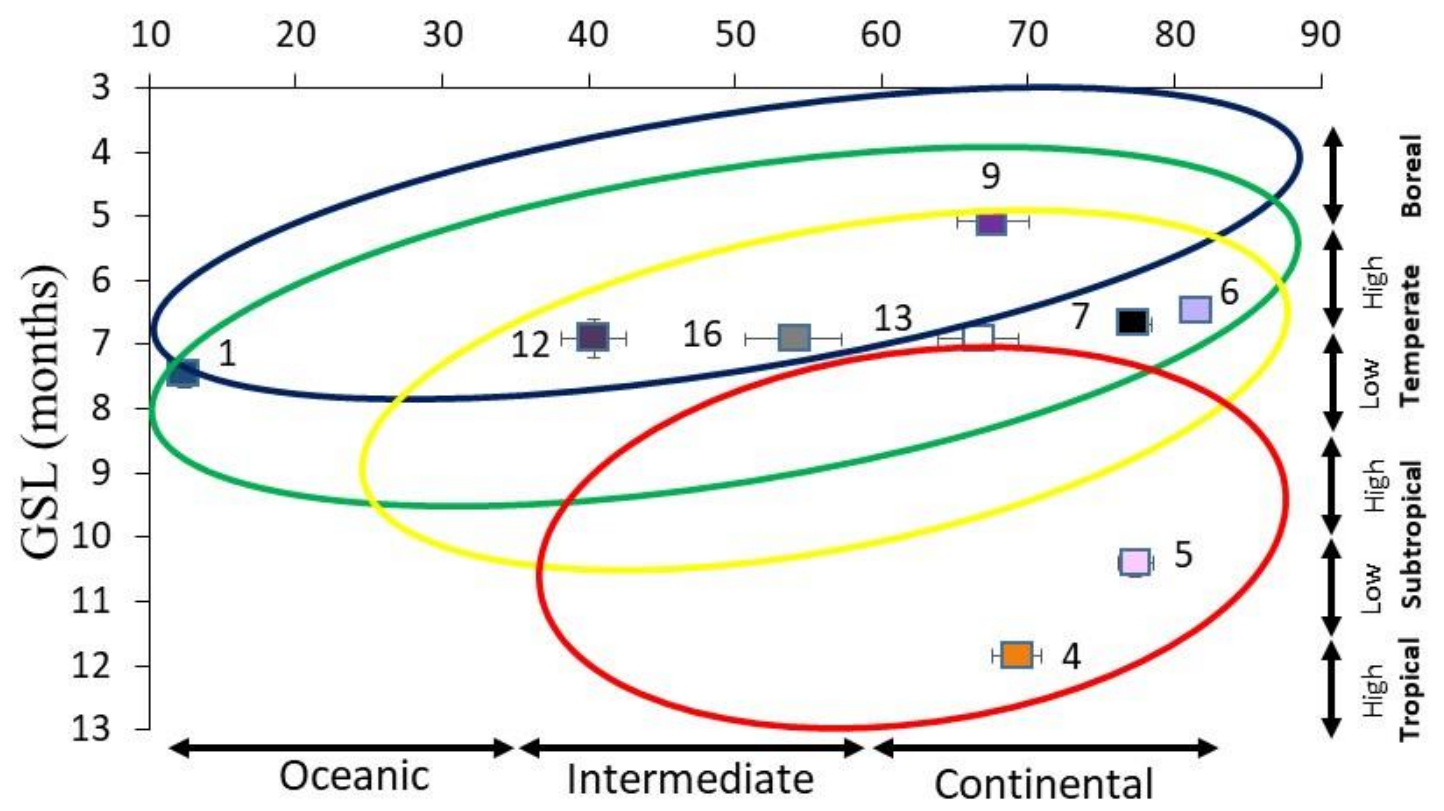


702 Short titles for the appendices:

703 Appendix 1:

704 Fig. S1.1: Eigenvalues of the five RDA axes.

705 Appendix 2:

706 Table S2.2: Occurrence of species in the 16 cluster groups.

707 Appendix 3:

708 Fig. S3.3: Means ( \pm 1 SE) of W GAMS (a), Tmin (b) and S ARID (c) for the 16 cluster 709 groups.

710 